\title{
PENGARUH PUPUK BIO-SLURRY PADAT DENGAN KOMBINASI DOSIS PUPUK NPK PADA PERTUMBUHAN DAN PRODUKSI JAGUNG MANIS (Zea mays saccharata Sturt)
}

\author{
Rindang Wicaksono', Darwin H. Pangaribuan², Akari Edy² \& Hidayat Pujisiswanto² \\ ${ }^{1}$ Mahasiswa Jurusan Agroteknologi, Fakultas Pertanian Universitas Lampung \\ ${ }^{2}$ Dosen Jurusan Agroteknologi, Fakultas Pertanian Universitas Lampung \\ Jl. Sumantri Brojonegoro No.1 Bandar Lampung 35145 \\ Email: rindang.wicaksono150@gmail.com
}

\begin{abstract}
ABSTRAK
Produktivitas jagung manis di Indonesia saat ini masih jauh di bawah potensi. Salah satu upaya untuk meningkatkan hasil jagung manis adalah dengan pemupukan yang tepat. Penelitian ini bertujuan untuk mengetahui respon dan kombinasi terbaik antara pemberian pupuk Bio-slurry padat dengan pupuk anorganik NPK terhadap pertumbuhan dan produksi tanaman jagung manis varietas Jambore. Penelitian dilaksanakan di lahan petani Desa Fajar Baru, Dusun Tanjung Laut, Kecamatan Jati Agung, Kabupaten Lampung Selatan. Rancangan percobaan yang digunakan adalah Rancangan Acak Kelompok (RAK) dengan rancangan faktorial $(2 \mathrm{x} 4)$ dan diulang tiga kali. Hasil penelitian menunjukkan pemberian pupuk Bio-slurry 20 t/ha dapat meningkatkan tinggi tanaman 5 MST, jumlah daun 5 MST, tingkat kehijauan daun lebih tinggi, bobot berangkasan basa lebih berat, tingkat kemanisan $\left({ }^{0}\right.$ Brix $)$ lebih tinggi, diameter tongkol lebih besar, jumlah baris per tongkol lebih banyak, bobot tongkol tanpa kelobot dan produksi per petak lebih tinggi. Kombinasi dosis terbaik antara pupuk Bio-slurry padat dan pupuk NPK adalah pada taraf pupuk Bio-slurry 20 t/ha dan NPK taraf $150 \mathrm{~kg} / \mathrm{ha}$.
\end{abstract}

Kata kunci: Bio-slurry, Kultivar Jambore.

\section{PENDAHULUAN}

Jagung manis (Zea mays L.Saccharata Sturt.)

adalah salah satu tanaman yang disukai oleh masyarakat di Indonoesia. Produktivitas jagung manis di Indonesia tercatat sebesar 4,79t/ha. Produktivitas tersebut masih jauh dibawah potensi hasil jagung manis yang mampu mencapai 14-18 t/ha padahal setiap tahun diperkirakan akan terus meningkat seiring dengan bertambahnya jumlah penduduk dan peningkatan daya beli masyarakat (Direktorat Jendral Tanaman Pangan, 2016). Hal tersebut mendorong petani agar dapat meningkatkan produksi dengan meningkatkan kemampuan budidayanya.

Salah satu upaya untuk meningkatkan hasil jagung manis adalah dengan pemupukan yang tepat. Pemupukan adalah suatu tindakan memberikan tambahan unsur hara pada tanah baik langsung maupun tak langsung. Pertumbuhan dan perkembangan tanaman sangat dipengaruhi oleh pemberian pupuk dan ketersediaan unsur hara di dalam tanah (Irvan, 2013).

Pupuk anorganik merupakan pupuk yang banyak digunakan dan sangat dibutuhkan dalam 
pertumbuhan tanaman. Salah satu pupuk anorganik yang digunakan diantaranya adalah pupuk NPK. NPK merupakan pupuk majemuk dengan kandungan unsur hara makro yang dibutuhkan tanaman dalam pertumbuhan tanaman (Sutedjo, 2010). Meski dampak dari penggunaan pupuk anorganik menghasilkan peningkatan produktivitas tanaman yang cukup tinggi namun menurut Parman (2007) penggunaan pupuk anorganik yang berlebihan dan dalam jangka yang relatif lama dapat berakibat buruk pada kondisi tanah. Tanah menjadi cepat mengeras, kurang mampu menyimpan air dan cepat menjadi asam yang pada akhirnya akan menurunkan produktivitas tanaman.

Pupuk Bio-slurry atau ampas biogas merupakan pupuk yang berasal dari hasil pengolahan biogas berbahan campuran kotoran ternak dan air melalui proses tanpa oksigen (anaerobik) di dalam ruang tertutup bertekstur lengket dan mempunyai kemampuan untuk mengikat air dengan baik (Warnars dan Oppenoorth, 2014). Karki (2001) menjelaskan pupuk Bio-slurry baik untuk menyuburkan lahan dan meningkatkan produksi tanaman budidaya karena mengandung bahan organik yang cukup tinggi. Tanah yang diberi pupuk bio- slurry menjadi gembur sehingga tanaman jagung manis lebih mudah mengikat unsur hara dan air.

Pupuk organik Bio-slurry padat yang dikombinasikan dengan pupuk anorganik NPK dapat menjadi alternatif untuk mengurangi kerusakan dan menjaga kesuburan tanah. Kombinasi antara kedua pupuk tersebut sangat berpotensi dalam meningkatkan produksi jagung manis. Penelitian ini bertujuan untuk mengetahui respon dan kombinasi terbaik antara pemberian pupuk Bio-slurry padat dengan pupuk anorganik NPK terhadap pertumbuhan dan produksi tanaman jagung manis varietas Jambore.

\section{BAHAN DAN METODE}

Penelitian dilakukan di lahan petani Desa Fajar Baru, Dusun Tanjung Laut, Kecamatan Jati Agung, Kabupaten Lampung Selatan. Bahan-bahan yang digunakan pada penelitian ini adalah benih jagung manis (Zea mays saccharata) varietas Jambore, pupuk Bioslurry padat dan pupuk NPK mutiara.

Penelitian ini menggunakan rancangan acak kelompok dengan kombinasi dua faktor antara pupuk Bio-slurry padat (B) terdiri dari dua taraf (B1: 0 t/ha dan B2 : $20 \mathrm{t} / \mathrm{ha}$ ) sebagai petak utama dan pupuk anorganik NPK (C) terdiri dari 4 taraf (C1: $150 \mathrm{~kg}$ / ha ; C2: $225 \mathrm{~kg} / \mathrm{ha}$; C3: $300 \mathrm{~kg} / \mathrm{ha}$; C4: $375 \mathrm{~kg} / \mathrm{ha}$ ) sebagai anak petak. Masing-masing perlakuan diulang sebanyak 3 kali sehingga diperoleh 24 unit percobaan. Hogenitas ragam diuji dengan menggunakan uji Bartlett dan aditivitas diuji dengan menggunakan uji Tukey, selajutnya data dianalisis dengan sidik ragam dan dilanjutkan dengan uji BNT.

\section{Pengolahan tanah dilakukan dengan} pengolahan sempurna dengan 2 kali olah tanah, petak berukuran $2 \times 3 \mathrm{~m}$ sebanyak 24 petak dengan jarak antar petak $0,5 \mathrm{~m}$, dan antar ulangan $1 \mathrm{~m}$, dengan jarak tanam 70 X $30 \mathrm{~cm}$ sehingga tiap petak terdapat 24 tanaman. Pemberian pupuk Bio Slurry dilakukan saat pengolahan tanah kedua dengan mencampur pupuk dengan tanah. Pemberian pupuk NPK dilakukan pada usia 2 minggu setelah tanam pada pagi hari dengan cara 
di tugal pada jarak $5 \mathrm{~cm}$. Pada penelitian ini dilakukan pengukuran terhadap beberapa variabel pengamatan pada tanaman sampel yaitu tinggi tanaman 5 minggu setelah tanam (MST), jumlah daun 5 MST, tingkat kehijauan daun, bobot berangkasan basah, tingkat kemanisan, diameter tongkol, jumlah baris pertongkol, bobot tongkol tanpa kelobot, produksi tanaman per petak.

\section{HASIL DAN PEMBAHASAN}

Tanah yang dijadikan sebagai lahan penelitian merupakan jenis tanah Ultisol yang pernah diaplikasikan pupuk Bio-slurry dan ditanami bunga kol pada pertanaman sebelumnya. Dari hasil analisis tanah di golongkan dengan standar sifat kimia tanah Hardjowigeno (2003) (Tabel 1). Menunjukkan nilai pH- $\mathrm{H}_{2} \mathrm{O}$ yaitu 4,75 yang tergolong dalam kondisi masam. Kandungan N-total 0,013\%, P-tersedia 6,23 ppm dan Kalium $\left(\mathrm{K}_{2} \mathrm{O}\right)$ 2,22 mg/100g tergolong sangat rendah untuk pertanaman. Sedangkan kandungan bahan organik juga masih tergolong rendah yaitu 4,26\%. Namun nilai C-Organik tanah tergolong sedang yaitu 2,36 \%. Tanah Ultisol, umumnya berkembang dari bahan induk tua. masalah tanah ini adalah pH masam, kadar Al tingggi sehingga menjadi racun tanaman dan menyebabkan fiksasi P sehingga unsur hara rendah (Hardjowigeno, 2003). Hanafiah (2012) menjelaskan bahwa C-organik dapat meningkatkan kemampuan menyangga dan menyediakan hara tanaman, meningkatkan efisiensi pemupukan, menetralkan sifat racun $\mathrm{Al}$ dan Fe, sumber energi bagi jasad renik / mikroba tanah yang mampu melepaskan hara bagi tanaman.

Karbon merupakan sumber makanan mikroorganisme tanah, sehingga kegiatan mikro organisme pun akan terpacu seperti proses dekomposisi tanah dan juga reaksi-reaksi yang memerlukan bantuan seperti pelarutan P dan fiksasi N (Utami, 2003). Hal ini juga erat kaitannya dengan besar kecilnya kapasitas tukar kation (KTK) yang merupakan jumlah total kation yang dapat dipertukarkan pada permukaan koloid yang bermuatan negatif. Semakin tinggi KTK maka semakin banyak pula kation yang dapat ditariknya. Bahan organik banyak menjerap ion $\mathrm{H}^{+}$atau $\mathrm{Al}^{+}$. Kation yang terjerap dalam tanah akan dapat dilepaskan dari tanah dan ditukar tempatnya oleh ion $\mathrm{H}^{+}$yang dilepaskan oleh akar tanaman. Kation yang berupa unsur hara itu

Tabel 1. Analisis kesuburan tanah

\begin{tabular}{|c|c|c|}
\hline Parameter & Kandungan & Keterangan \\
\hline $\mathrm{pH}-\mathrm{H}_{2} \mathrm{O}$ & 4,75 & Masam \\
\hline N-Total (\%) & 0,013 & Sangat rendah \\
\hline P-tersedia (ppm) & 6,23 & Sangat rendah \\
\hline Kalium (K2O) (mg/100 g) & 2,22 & Sangat rendah \\
\hline C-Organik (\%) & 2,36 & Sedang \\
\hline Bahan Organik (\%) & 4,26 & Rendah \\
\hline
\end{tabular}

Keterangan: Analisis tanah dilakukan di Laboratorium Analisis Polinela menggunakan metode Kjedahl-Spektro (N-Total), Spektophotometri (P-tersedia), AAS (Kalium), Walkley-Black (C-Organik dan Bahan Organik). 
kemudian larut dalam air tanah dan diserap oleh tanaman.

Hasil pertumbuhan dan perkembangan vegetatif tanaman (Tabel2) menunjukkan penambahan pupuk Bio-slurry 20 t/ha dapat meningkatkan hasil dari tinggi tanaman dengan selisih $13,53 \mathrm{~cm}$, jumlah daun bertambah dengan selisih 1,24 helai dan tingkat kehijauan daun lebih besar dengan selisih 4,53 dibandingkan dengan tanpa pemberian pupuk Bioslurry. Hal tersebut menunjukkan bahwa pemberian pupuk Bio-slurry baik dalam membantu penyediaan unsur hara bagi tanaman. Seperti yang diungkapkan oleh Hanafiah (2012) bahwa pupuk organik berperan dalam memperbaiki sifat kimia, fisik dan biologi tanah. Hal ini penting, karena selain kandungan unsur hara yang mencukupi, kondisi struktur tanah juga menentukan dapat atau tidaknya unsur hara dalam tanah tersebut diserap dengan baik oleh tanaman. Pertumbuhan dan perkembangan vegetatif jagung terhadap pemberian pupuk NPK pada tinggi tanaman taraf $375 \mathrm{~kg} / \mathrm{ha}$ menunjukkan hasil yang lebih tinggi dibandingkan dengan taraf yang lainnya. Sedangkan pada jumlah daun menunjukkan hasil rata-rata yang sama pada semua taraf NPK. Pada tingkat kehijauan daun menunjukkan hasil yang cenderung linier meningkat dari taraf NPK terendah ke taraf tertinggi.

Hasil rata-rata jumlah daun yang sama pada semua taraf pemberian pupuk NPK dipengaruhi oleh sifat genetik tanaman jagung tersebut. Menurut Utami (2003) jumlah daun dalam satu tanaman ditentukan oleh sedikitnya primordia daun yang terbentuk pada tanaman tersebut. Tingkat kehijauan daun ini dapat digunakan untuk mengetahui ketersediaan unsur hara oleh tanaman terutama unsur nitrogen. Pada pemberian pupuk Bioslurry 20 t/ha menunjukkan hasil yang lebih tinggi dibandingkan dengan tanpa pemberian pupuk Bioslurry 0 t/ha. Martajaya (2010) menyatakan Nitrogen (N) dalam Bio-slurry sebagian tersedia sebagai senyawa amonium majemuk $\left(\mathrm{NH}_{4}^{+}\right)$dan sebagai organik N. N Organik hanya tersedia untuk serapan tanaman setelah mineralisasi ke anorganik N. N mineralisasi produk organik sangat bergantung pada dekomposabilitas dan rasio $\mathrm{C} / \mathrm{N}$ dari bahan organik dalam produk. Nitrogen terdapat dalam protoplasma

Tabel 2. Hasil pertumbuhan dan perkembangan vegetatif

\begin{tabular}{lccc}
\hline Perlakuan & $\begin{array}{c}\text { Tinggi tanaman } \\
(\mathrm{cm})\end{array}$ & $\begin{array}{c}\text { Jumlah Daun } \\
(\text { helai })\end{array}$ & $\begin{array}{c}\text { Tingkat Kehijauan Daun } \\
\text { SPAD }\end{array}$ \\
\hline Dosis pupuk Bio-slurry & & & \\
0 t/ha & $85,38 \mathrm{a}$ & $7,03 \mathrm{a}$ & $44,91 \mathrm{a}$ \\
$20 \mathrm{t} / \mathrm{ha}$ & $98,91 \mathrm{~b}$ & $8,27 \mathrm{~b}$ & $49,34 \mathrm{~b}$ \\
Dosis pupuk NPK & & & \\
$150 \mathrm{~kg} / \mathrm{ha}$ & $90,13 \mathrm{a}$ & $7,23 \mathrm{a}$ & $43,94 \mathrm{a}$ \\
$225 \mathrm{~kg} / \mathrm{ha}$ & $93,35 \mathrm{a}$ & $7,67 \mathrm{a}$ & $45,34 \mathrm{a}$ \\
$300 \mathrm{~kg} / \mathrm{ha}$ & $88,55 \mathrm{a}$ & $7,60 \mathrm{a}$ & $49,47 \mathrm{~b}$ \\
$375 \mathrm{~kg} / \mathrm{ha}$ & $96,55 \mathrm{~b}$ & $8,10 \mathrm{a}$ & $49,75 \mathrm{~b}$ \\
\hline
\end{tabular}

Keterangan : Angka-angka yang diikuti dengan huruf yang sama pada setiap kolom menunjukkan pengaruh yang tidak berbeda nyata berdasarkan pengujian BNT 5\%. 
sel tanaman yang diperlukan untuk semua proses pertumbuhan dan merupakan bagian dari klorofil.

Hasil pertumbuhan dan perkembangan generatif (Tabel 3) pada pemberian pupuk Bio-slurry 20 t/ha menunjukkan bobot berangkasan basah lebih berat dengan selisih $0,11 \mathrm{~kg}$, tingkat kemanisan lebih manis dengan selisih $0,95^{\circ}$ Brix, diameter tongkol lebih besar dengan selisih $0,20 \mathrm{~cm}$, jumlah baris pertongkol lebih banyak dengan selisih 0,99 baris, bobot tongkol tanpa kelobot lebih berat dengan selisih $0,09 \mathrm{~kg}$, dan produksi per petak yang lebih tinggi dengan selisih 0,94 kg dibandingkan tanpa pemberian pupuk Bioslurry. Sedangkan pada pemberian pupuk NPK menunjukkan bobot berangkasan basah, tingkat kemanisan, diameter tongkol, jumlah baris pertongkol, bobot tongkol tanpa kelobot, dan produksi per petak memberikan hasil yang sama pada semua taraf pemberian pupuk NPK.

Bobot berangkasan basah dipengaruhi oleh pertumbuhan vegetatif. Pemberian pupuk Bio-slurry dapat meningkatkan penyerapan unsur hara dalam tanaman menjadi lebih efektif. Hal tersebut sesuai dengan pernyataan Husma (2010) bahwa pemberian bahan organik berpengaruh terhadap tanaman seperti peningkatan kegiatan respirasi, bertambah lebarnya daun yang berpengaruh pada kegiatan fotosintesis yang bermuara pada produksi. Hasil nilai Brix atau kandungan gula pada pemberian pupuk Bio-slurry 20 t/ha menghasilkan nilai Brix yang lebih tinggi yaitu 13,18 Brix dibandingkan tanpa pemberian Bio-slurry. Pemberian pupuk NPK tidak berbeda nyata pada semua taraf. Dengan nilai brik tertinggi pada taraf NPK $375 \mathrm{~kg} /$ ha yaitu 13,02 Brix. Hasil tersebut sesuai dengan deskripsi jagung varietas jambore yang memiliki nilai Brix sekitar 13,5 Brix. Menurut Novizan (2002) Unsur hara yang penting dalam pembentukkan tongkol jagung manis adalah unsur hara K. Hal ini didukung oleh Sutejo(2010) padajagung manis pemberian kalium

Tabel 3. Hasil pertumbuhan dan perkembangan generatif

\begin{tabular}{lcccccc}
\hline \multicolumn{1}{c}{ Perlakuan } & $\begin{array}{c}\text { Bobot } \\
\text { Berangkasan } \\
\text { Basah (Kg) }\end{array}$ & $\begin{array}{c}\text { Tingkat } \\
\text { Kemanisan } \\
\left({ }^{0} \text { Brix }\right)\end{array}$ & $\begin{array}{c}\text { Diameter } \\
\text { Tongkol } \\
(\mathrm{cm})\end{array}$ & $\begin{array}{c}\text { Jumlah } \\
\text { Baris } \\
\text { Pertongkol } \\
(\text { baris })\end{array}$ & $\begin{array}{c}\text { Bobot } \\
\text { tongkol } \\
\text { tanpa } \\
\text { kelobot }(\mathrm{kg})\end{array}$ & $\begin{array}{c}\text { Produksi } \\
\text { per petak } \\
(\mathrm{kg})\end{array}$ \\
\hline $\begin{array}{l}\text { Dosis pupuk Bio-slurry } \\
0 \mathrm{t} / \mathrm{ha}\end{array}$ & $0,87 \mathrm{a}$ & $12,23 \mathrm{a}$ & $4,09 \mathrm{a}$ & $15,88 \mathrm{a}$ & $0,77 \mathrm{a}$ & $4,82 \mathrm{a}$ \\
$20 \mathrm{t} / \mathrm{ha}$ & $0,98 \mathrm{~b}$ & $13,18 \mathrm{~b}$ & $4,29 \mathrm{~b}$ & $16,87 \mathrm{~b}$ & $0,86 \mathrm{~b}$ & $5,76 \mathrm{~b}$ \\
Dosis pupuk NPK & & & & & & \\
$150 \mathrm{~kg} / \mathrm{ha}$ & $0,86 \mathrm{a}$ & $12,47 \mathrm{a}$ & $4,18 \mathrm{a}$ & $16,20 \mathrm{a}$ & $0,79 \mathrm{a}$ & $5,04 \mathrm{a}$ \\
$225 \mathrm{~kg} / \mathrm{ha}$ & $0,92 \mathrm{a}$ & $12,63 \mathrm{a}$ & $4,18 \mathrm{a}$ & $16,37 \mathrm{a}$ & $0,80 \mathrm{a}$ & $5,25 \mathrm{a}$ \\
$300 \mathrm{~kg} / \mathrm{ha}$ & $0,96 \mathrm{a}$ & $12,70 \mathrm{a}$ & $4,17 \mathrm{a}$ & $16,43 \mathrm{a}$ & $0,83 \mathrm{a}$ & $5,40 \mathrm{a}$ \\
$375 \mathrm{~kg} / \mathrm{ha}$ & $0,96 \mathrm{a}$ & $13,02 \mathrm{a}$ & $4,23 \mathrm{a}$ & $16,50 \mathrm{a}$ & $0,85 \mathrm{a}$ & $5,48 \mathrm{a}$ \\
\hline
\end{tabular}

Keterangan : Angka-angka yang diikuti dengan huruf yang sama pada setiap kolom menunjukkan pengaruh yang tidak berbeda nyata berdasarkan pengujian BNT 5\%. 
pada jagung manis dapat meningkatkan kandungan gula, karena dapat merangsang translokasi fotosintat ke semua jaringan tanaman.

Diameter tongkol sangat dipengaruhi oleh penyediaan unsur hara pada masa pengisian biji, pemberian pupuk Bio-slurry ini dapat mempertahankan unsur hara dalam tanah sehingga masih dapat tersedia untuk tanaman, sehingga pada saat pengisian biji unsur hara masih banyak tersedia dibandingkan dengan tanpa pemberian pupuk Bio-slurry. Selain mengandung unsur hara pupuk Bio-slurry juga memiliki tekstur yang lengket dan memiliki kemampuan untuk mengikat air dan unsur hara dengan baik (Tim Biru, 2013).

Kekurangan unsur hara juga dapat menyebabkan gagalnya pengisian biji di ujung tongkol, kekurangan Kalium menyebabkan pengisian biji di ujung tongkol tidak baik dan susunan butiran yang longgar. Kekurangan Phospor menggangu polinasi dan pengisian biji. Tongkol menjadi kecil dan melengkung karena perkembangan pengisian biji yang tidak sempurna serta kosongnya biji pada ujung tongkol, hal ini sesuai dengan hasil penelitian Syafruddin dkk. (2012). Selain pengaruh pupuk, jumlah baris dalam tongkol pun diduga dipengaruhi oleh faktor genetik. Hasil penelitian ini sejalan dengan pendapat Subekti dkk. (2008) bahwa jumlah baris lebih dipengaruhi oleh faktor genetik, sehingga pemberian beberapa dosis pupuk akan menghasilkan jumlah baris yang relatif sama.

Peningkatan berat tongkol sangat erat hubungannya dengan besar fotosintat yang dialirkan kebagian tongkol. Pemberian pupuk Bio-slurry selain menambah unsur hara juga dapat memperbaiki sifatsifat tanah sehingga dapat meminimalisir hilangnya hara. Tanah yang diberi pupuk Bio-slurry menjadi gembur sehingga tanaman jagung manis lebih mudah mengikat unsur hara dan air (Tim Biru, 2013).

Hasil uji korelasi peubah vegetatif dan generatif melalui uji korelasi Pearson (Tabel 4) menunjukkan tinggi tanaman dan tingkat kehijauan daun berkorelasi berbeda nyata terhadap produksi perpetak jagung manis sedangkan jumlah daun, bobot berangkaan basah, diameter dan jumlah baris pertongkol sangat mempengaruhi hasil bobot tongkol tanpa kelobot. Hal ini dibuktikan dengan pengujian korelasi peubah generatif dan vegetatif pada Tabel 4 sedangkan berdasarkan pengujian, jumlah daun, bobot berangkasan basah, tingkat kemanisan, diameter tongkol, jumlah baris pertongkol menunjukkan hasil korelasi yang sangat berbeda nyata. Pada tinggi tanaman menunjukkan tidak dipengaruhi oleh tingkat kehijauan daun dan bobot berangkasan basah. Sedangkan tingkat kehijauan daun juga tidak berpengaruh terhadap diameter tongkol.

\section{KESIMPULAN}

Penelitian ini menyimpulkan bahwa pada pemberian pupuk Bio-slurry 20 t/ha dapat meningkatkan tinggi tanaman, jumlah daun lebih banyak, tingkat kehijauan daun meningkat, bobot berangkasan basa lebih berat, tingkat kemanisan lebih manis, diameter tongkol lebih besar, jumlah baris per tongkol lebih banyak, bobot tongkol tanpa kelobot, dan produksi per petak lebih berat. Pada lahan dengan kandungan C-organik sedang dengan pemberian pupuk 
Tabel 4. Hasil uji korelasi peubah vegetatif dan generatif melalui uji korelasi Pearson

\begin{tabular}{|c|c|c|c|c|c|c|c|c|c|}
\hline Peubah & $\begin{array}{l}\text { Tinggi } \\
\text { Tanaman }\end{array}$ & $\begin{array}{l}\text { Jumlah } \\
\text { Daun }\end{array}$ & $\begin{array}{l}\text { Tingkat } \\
\text { Kehijauan } \\
\text { Daun }\end{array}$ & $\begin{array}{c}\text { Bobot } \\
\text { Berangkasan } \\
\text { Basah }\end{array}$ & $\begin{array}{l}\text { Tingkat } \\
\text { Kemanisan }\end{array}$ & $\begin{array}{l}\text { Diameter } \\
\text { Tongkol }\end{array}$ & $\begin{array}{c}\text { Jumlah } \\
\text { Baris } \\
\text { Pertongkol }\end{array}$ & $\begin{array}{l}\text { Bobot } \\
\text { Tongkol } \\
\text { Tanpa } \\
\text { Kelobot }\end{array}$ & $\begin{array}{l}\text { Produksi } \\
\text { Perpetak }\end{array}$ \\
\hline $\begin{array}{l}\text { Tinggi } \\
\text { Tanaman }\end{array}$ & 1 & $0.936^{* *}$ & 0.551 & 0.699 & $0.924^{* * *}$ & $0.950^{* *}$ & $0.886^{* * *}$ & $0.819^{*}$ & $0.857^{*}$ \\
\hline $\begin{array}{l}\text { Jumlah } \\
\text { Daun }\end{array}$ & $0.936^{* *}$ & 1 & $0.800^{*}$ & $0.903^{* *}$ & $0.987^{* *}$ & $0.920^{* *}$ & $0.940^{* * *}$ & $0.949^{* *}$ & $0.961^{* *}$ \\
\hline $\begin{array}{l}\text { Tingkat Kehijauan } \\
\text { Daun }\end{array}$ & 0.551 & $0.800^{*}$ & 1 & $0.941^{* *}$ & $0.816^{*}$ & 0.620 & $0.735^{*}$ & $0.912^{* *}$ & $0.835^{*}$ \\
\hline $\begin{array}{l}\text { Bobot Berangkasan } \\
\text { Basah }\end{array}$ & 0.699 & $0.903^{* *}$ & $0.941^{* * *}$ & 1 & $0.892^{* *}$ & $0.737^{*}$ & $0.870^{*}$ & $0.935^{* *}$ & $0.936^{* *}$ \\
\hline $\begin{array}{l}\text { Tingkat } \\
\text { Kemanisan }\end{array}$ & $0.924^{* * *}$ & $0.987^{* *}$ & $0.816^{*}$ & $0.892^{* *}$ & 1 & $0.951^{* *}$ & $0.959^{* *}$ & $0.976^{* *}$ & $0.975^{* *}$ \\
\hline $\begin{array}{l}\text { Diameter } \\
\text { Tongkol }\end{array}$ & $0.950^{* * *}$ & $0.920^{* *}$ & 0.620 & $0.737^{*}$ & $0.951^{* * *}$ & 1 & $0.957^{* * *}$ & $0.886^{* *}$ & $0.922^{* *}$ \\
\hline $\begin{array}{l}\text { Jumlah Baris } \\
\text { Pertongkol }\end{array}$ & $0.886^{* *}$ & $0.940^{* *}$ & $0.735^{*}$ & $0.870^{*}$ & $0.959^{* *}$ & $0.957^{* * *}$ & 1 & $0.927^{* *}$ & $0.986^{* *}$ \\
\hline $\begin{array}{l}\text { Bobot Tongkol Tanpa } \\
\text { Kelobot }\end{array}$ & $0.819^{*}$ & $0.949^{* * *}$ & $0.912^{* *}$ & $0.935^{* *}$ & $0.976^{* *}$ & $0.886^{* *}$ & $0.927^{* *}$ & 1 & $0.970^{* *}$ \\
\hline $\begin{array}{l}\text { Produksi } \\
\text { Perpetak }\end{array}$ & $0.857^{*}$ & $0.961^{* * *}$ & $0.835^{*}$ & $0.936^{* *}$ & $0.975^{* *}$ & $0.922^{* *}$ & $0.986^{* *}$ & $0.970^{* *}$ & 1 \\
\hline
\end{tabular}

Keterangan: $*=$ korelasi berbeda nyata pada taraf $5 \% ; * *=$ korelasi sangat berbeda nyata pada taraf $1 \%$.

Bio-slurry padat $20 \mathrm{t} / \mathrm{ha}$ dapat mengurangi penggunaan pupuk NPK $50 \%$ dari rekomendasi $(150 \mathrm{~kg} / \mathrm{ha})$.

\section{DAFTAR PUSTAKA}

Direktorat Jendral Tanaman Pangan. 2016. Pedoman Pelaksanaan Kegiatan Jagung Tahun 2017. Kementerian Pertanian. Jakarta. $92 \mathrm{hlm}$.

Hanafiah, K. A. 2012. Dasar-Dasar Ilmu Tanah. Raja Grafindo Persada. Jakarta. $386 \mathrm{hlm}$.

Hardjowigeno, S. 2003. Ilmu Tanah. Akademika Pressindo. Jakarta. $288 \mathrm{hlm}$.

Husma, M. 2010. Pengaruh Bahan Organik dan Pupuk Kaliun terhadap Pertumbuhan dan Produksi Tanaman Melon (Curcumis melo L). Tesis. Program Studi Agronomi Universitas Haluoleo. $50 \mathrm{hlm}$.
Irvan, M. 2013. Respon Bawang Merah (Allium Ascalonicum L.) terhadap Zat Pengatur Tumbuh dan Unsur Hara. Jurnal Agroteknologi. 3(2) : 35-40.

Karki. 2001. Response to Bio-slurry Application on Maize and Cabbage in Lalitpur District. Final report. Nepal. $49 \mathrm{hlm}$.

Martajaya, M., L. Agustina, dan Syekhfani. 2010. Metode budidaya organik tanaman jagung manis di Tlogomas, Malang. Jurnal Pembangunan dan Alam Lestari. 1(1):1-14.

Novizan. 2002. Petunjuk Pemupukan yang Efektif. Agro Media. Pustaka. Jakarta. $116 \mathrm{hlm}$.

Parman, S. 2007. Pengaruh Pemberian Pupuk Organik Cair Terhadap Pertumbuhan dan Produksi Kentang (Solanum Tuberosum L.). Buletin Anatomi dan fisiologi Vol. XV. No. 2. 
Subekti, N. A., Syafruddin, R. Efendi dan S. Sunarti. 2008. Morfologi Tanaman dan Fase Pertumbuhan Jagung. Balai Penelitian Tanaman Serealia. Maros. $37 \mathrm{hlm}$.

Sutedjo, M. M. 2010. Pupuk dan Cara Pemupukan. Rineka Cipta. Jakarta. $175 \mathrm{hlm}$.

Syafruddin, Nurhayati dan R. Wati. 2012. Pengaruh Jenis Pupuk terhadap Pertumbuhan dan Hasil Beberapa Varietas Jagung Manis (Zea mays L. Saccharata Sturt). Jurnal Floratek. 7(1): 108-113.
Tim Biru. 2013. Pedoman Pengguna Pengawas Pengelolaan dan Pemanfaatan Bio-slurry. Tim Biogas Rumah. Jakarta. $31 \mathrm{hlm}$.

Utami, S. N., dan Handayani, S. 2003. Sifat Kimia Entisol Pada Sistem Pertanian Organik. Ilmu Pertanian. 10(2) :11-19.

Warnars, L. dan H. Oppenoorth. 2014. Bioslurry : A Supreme Fertiliser. Jurnal Hivos. 3(2) : 6-50. 